\title{
Late Calcification and Rupture: A Rare Complication of Ventriculoperitoneal Shunting
}

\author{
Geç Kalsifikasyon ve Kopma: Ventriküloperitoneal Şantın Nadir Bir \\ Komplikasyonu
}

Cahit KURAL ${ }^{1}$, Alparslan KIRIK ${ }^{1}$, Serhat PUSAT ${ }^{1}$, Tolga SENTURK ${ }^{2}$, Yusuf IZCI ${ }^{1}$

${ }^{1}$ Gulhane Millitary Medical Academy, Department of Neurosurgery, Ankara, Turkey

${ }^{2}$ Gulhane Millitary Medical Academy, Department of Pathology, Ankara, Turkey

Correspondence address: Yusuf IZCI / E-mail: yusufizci@yahoo.com

\begin{abstract}
A 10-year old boy who had undergone a ventriculoperitoneal (V/P) shunt because of hydrocephalus at 10 days of age was doing well until 20 days ago, when he began to experience headache and seizures. CT scan reveraled dilated lateral ventricles and calcification at the shunt site. X-rays showed an unusual calcification pattern around the shunt tube and rupture of the tube between the mastoid bone and clavicle. The patient underwent surgery and the shunt was changed completely. The ventricles became small in the follow-up. Even though V/P shunts may induce fibrous tissue formation and calcification around the tube, there are a few cases of shunt rupture and calcification of shunts in the literature. Possible mechanisms of the rupture and calcification are discussed in this paper.
\end{abstract}

KEYWORDS: Shunt, Calcification, Rupture

öz

On günlük iken hidrosefali tanısı ile ventriküloperitoneal (V/P) şant takılan 10 yaşında erkek çocuğu 20 gün öncesinde baş ağrısı ve nöbet şikayeti ortaya çıkana dek iyi imiş. Çekilen tomografisinde lateral ventriküllerde genişleme ve şant tarafında kalsifikasyon izlendi. Röntgende ise şant tüpü çevresinde sıra dışı bir kalsifikasyon olduğu ve tüpün mastoid kemik ile klavikula arasında koptuğu görüldü. Çocuk ameliyata alınarak şant komple değiştirildi. Takiplerinde ventriküllerin küçüldüğü görüldü. V/P şantlar tüp çevresinde fibröz doku formasyonu ve kalsifikasyon oluşumunu uyarmakla birlikte literatürde şantların kalsifikasyonu ve kopması çok nadir bildirilmiştir. Kalsifikasyonun ve kopmanın muhtemel mekanizmaları bu yazıda tartışıldı.

ANAHTAR SÖZCÜKLER: Şant, Kalsifikasyon, Kopma

\section{INTRODUCTION}

Ventriculoperitoneal (V/P) shunt is a widely used treatment method of hydrocephalus. Shunt failure is a common complication of this procedure, which requires shunt revision $(1,2)$. Even though the cause of shunt failure is usually an infection or obstruction (4), a few cases of calcification related shunt failure have been reported $(1,2,6,7,8)$.

In this paper, we aimed to emphasize the possibility of shunt disconnection, probably due to shunt calcification associated with patient's growth and neck movements. We also discuss about the possible causes of shunt calcification.

\section{CASE REPORT}

A 10-year-old old male patient was operated for noncommunicating hydrocephalus while he was 10 days old, and the V/P shunt had been inserted through the right Frazier's point. The patient was doing well till 20 days ago, when he presented with complaints of headache, seizure, and short periods of unconsciousness. The patient denied any trauma history, and his physical examination revealed the limited lateral gaze at the right eye with bilateral papilledema. The neurological examination was otherwise within normal limits. The restricted lateral gaze in the right eye was reported to develop within 6 months of the first operation. The serum and hematologic values of the patient were within normal limits and the skin at the site of shunt was not tender or inflamed. $X$-ray of the neck revealed the disconnection of the shunt at cervical region (Figure 1), and computed tomography (CT) scan showed dilatation of the lateral ventricles and focal calcifications (Figure 2).

The patient was operated on and the peritoneal part of shunt catheter was removed. No cerebrospinal fluid (CSF) leakage was noted through the shunt. Afterwards, with an incision at the cervical region, the disconnected sides of the catheter were found. The catheter was observed as fixed to subcutaneous tissue from cervical to abdominal region and was surrounded with a dense calcified fibrous tissue (Figure 3). The tips of the proximal and distal tubes were closed by fibrotic tissue, but the lumen of the shunt was not obstructed due to calcification. There was no CSF collection in 
the rupture region. After an incision at the Frazier's point, the valve of the $V / P$ shunt was found. It was also calcified and fixed to the cranium. After the removal of the ventricular catheter, the ventricles were controlled with a neuroendoscope, and choroid plexus calcification was observed. The new shunt was inserted through the same burr hole. The operation was terminated after verifying that the shunt was functioning well. Then, the peritoneal tip was inserted. Postoperative evaluation showed that blood calcium, phosphate, protein and $\mathrm{pH}$ values of the patient were within normal limits. CSF examination showed low levels of calcium and phosphate, and high levels of magnesium. Histopathologic examination of the specimens, which were obtained around the shunt tube, revealed dense fibrotic tissue in the outer zone and calcification in the inner zone (Figure 4A, B).

Postoperative physical examination revealed complete resolution of papilledema, but the restricted lateral gaze was

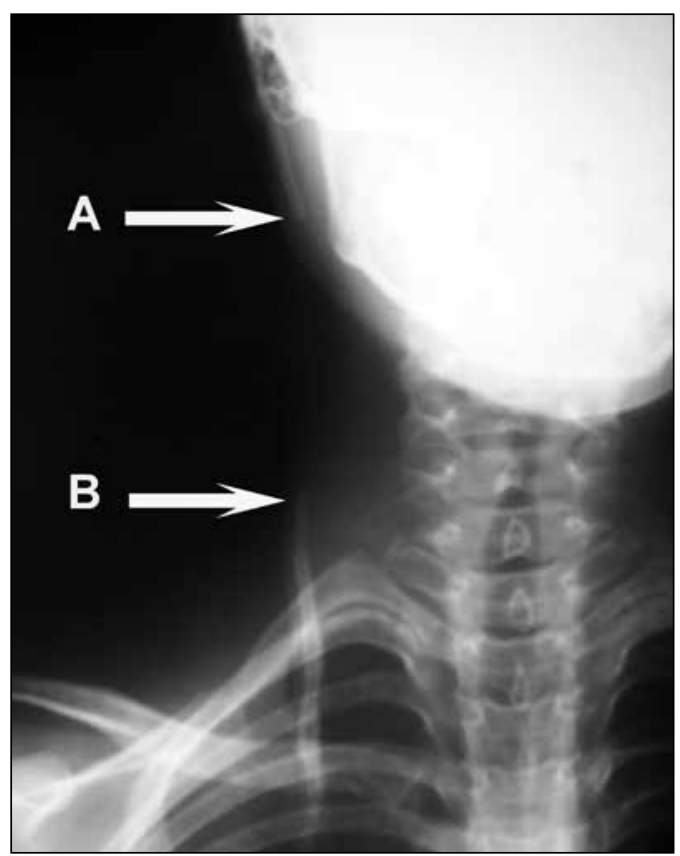

Figure 1: X-rays of the neck show rupture and disconnection of the ventriculoperitoneal shunt between the mastoid bone (A) and clavicle (B). Enlargement of the shunt distal tube due to calcification is also observed on the chest wall. still present, and the patient was discharged at postoperative $3^{\text {rd }}$ day. No more headache or seizure was observed after the operation.

\section{DISCUSSION}

V/P shunt insertions account for a significant number of neurosurgical admissions and procedures. Although they have resulted in dramatic improvements in patient survival and neurological function, shunts are associated with several complications (4). They can be complicated by malfunction due to obstruction, shunt disconnection or infection. Some of those complications require shunt revision. Calcification is avery rare cause of shunt failure and seldom reported in the literature $(1,2,6,7,8)$.

Peroxide-treated silicone (Silastic) catheter for the surgical treatment of hydrocephalus is employed since 1950. These catheters are used more frequenty than the other types,

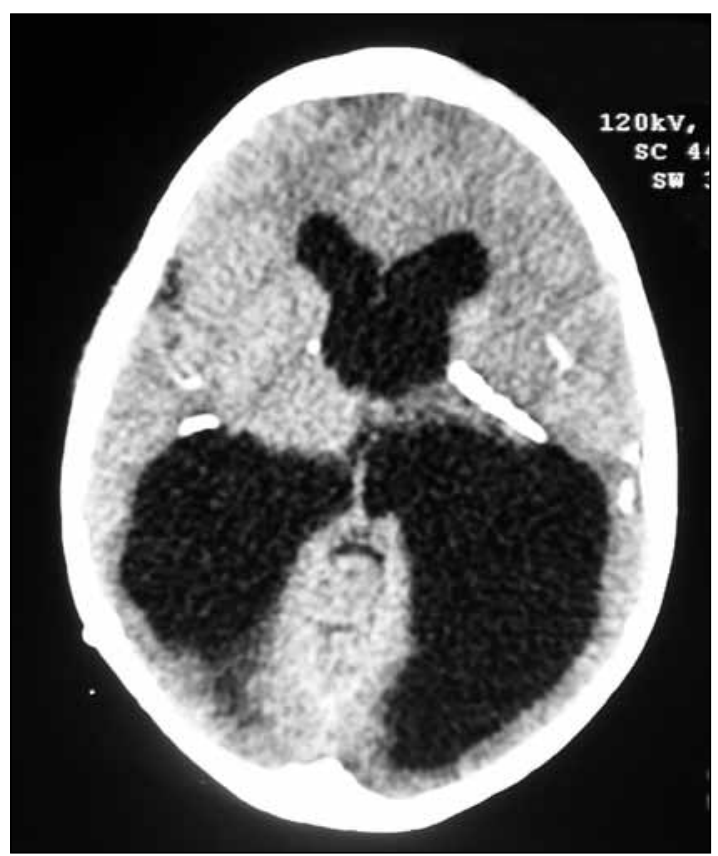

Figure 2: CT scan shows enlarged occipital horns of the lateral ventricles and calcifications in the brain.

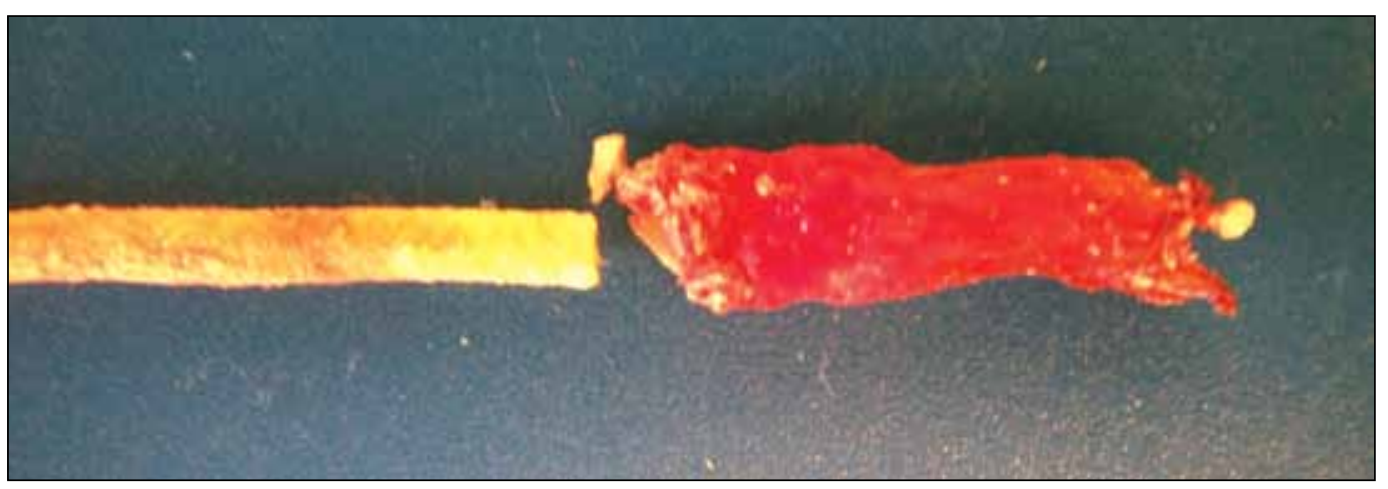

Figure 3: Macroscopic view of the calcified shunt tube and fibrocalcified tissue. 


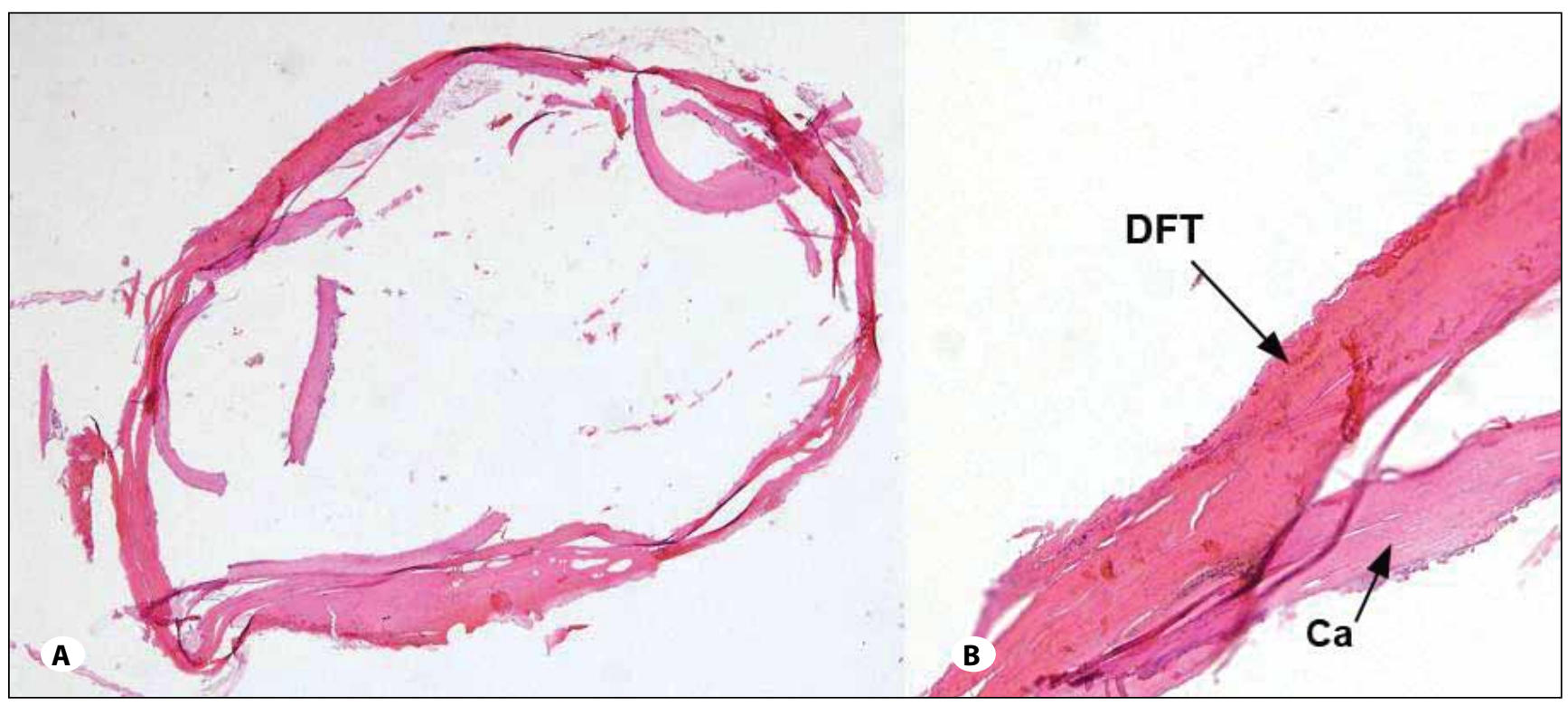

Figure 4: (A) Ring-like fibrocalcified zone is observed (H\&E, x40); (B) Dense fibrotic tissue (DFT) forms the outer zone and calcification (Ca) forms the inner zone of the specimen (H\&E, x400).

due to low incidence of tissue reaction and the softness of the material (3). First case report of degradation of shunt system dates back to 1983 and shunt calcification in 1988 (7). Although microscopic calcification of the tissues surrounding silastic shunt tubes seems to be common, calcification heavy enough to be apparent on plain radiographs is rare (8). Catheters become calcified, rigid, and fragile with aging of the shunt material. Consequently, they will migrate or break during the patient's growth (1). In our patient, the catheter was broken above the clavicle. When we removed the catheter, we saw that the catheter was very fragile and surrounded by a dense calcified material. We assumed that the degradation of the silicon catheter associated with the patient's growth and neck movements caused shunt disconnection.

Various factors have been suggested for calcium deposition around the shunt tubing. Variations in the quantity of silica and vulcanizing agent added to medical-grade silicone rubber may provoke a soft-tissue reaction. Static electrical charges on the tubing may hold dust and lint. Benzalkonium chloride may be absorbed into the silicone rubber and may reenter the body after implantation. Detergents and dissolved ethylene oxide gas may excite soft-tissue fibrosis. In addition, polymers are known to undergo biodegradation as a result of hydration, splitting of covalent bonds, and dissolution and digestion by macrophages $(2,3,5,9)$. Two mechanisms of calcification in vivo have been described: metastatic calcification associated with an increased concentration of calcium and phosphorus and dystrophic calcification, which is characterized by normal concentrations of phosphorus and calcium in the blood but altered cellular metabolism (1). The calcification seen in silicone implants is of the dystrophic type. The serum concentration of calcium and phosphorus remains normal even in those patients in whom calcification is seen very early, but accelerated formation of nuclei from the cellular debris that accumulate in proximity to the implant has been demonstrated. This formation of initial nuclei is occasionally furthered by physical imperfections of the catheter (cracks, surface irregularities related to element extrusion secondary to material aging, and formation of silanol groups) and by cellular foreign body reaction, resulting in cell aggregation on the surface of the implant (1). In our patient, serum calcium and phosphate levels were in normal limits, but CSF examination showed low levels of calcium and phosphate, and high levels of magnesium. These results showed that calcification in our patient was a dystrophic type.

Shunt calcification indicates degeneration and tethering of the shunt catheter. The tensile stresses on the tubing as it passes from the mobile neck to the relatively immobile chest wall may have been responsible for stress-related degeneration in the cervicothoracic section of the shunt (8). In view of the tethering of the tube associated with calcification, it is obvious that the disconnection of the catheter in the neck above the calcified segment, as seen in our case, may have been the result of tension on the tube during movements of the neck and patient's growth.

The most important factors in the microcalcification of the shunt catheters were the youth of the patient at original implantation and the length of time the tubing was in the patient. In our case, the patient was a newborn when the shunt was inserted and it was in the patient since 10 years of age. However, the clinical symptoms of hydrocephalus began within 20 days and the gap between the tips of the shunt tube was too large. We suppose that the shunt fracture and disconnection occurred many weeks ago, but the compliance of the brain delayed the symptoms of the hydrocephalus in this child. Our patient had no signs of acute shunt dysfunction but had the risk factors for shunt calcification. 
In conclusion, V/P shunts might not function due to calcification, and might disconnect or rupture with patient's growth or during neck movements. Therefore, close follow-up of shunts is necessary not only with CT scans, but also with neck, chest and abdominal x-rays. Shunt revision should be undertaken before the disconnection occurs.

\section{REFERENCES}

1. Boch AL, Hermelin E, Sainte-Rose C, Sgouros S: Mechanical dysfunction of ventriculoperitoneal shunts caused by calcification of the silicone rubber catheter. J Neurosurg 88 : 975-982, 1998

2. Cakir E, Kuzeyli K, Usul H, Peksoylu B, Karaarslan G, Yildiz $\mathrm{K}$ : Shunt dysfunction due to calcification of a ventriculoperitoneal shunt: A case report. J Clin Neurosci 11:210-211, 2004

3. Echizenya $K$, Satoh $M$, Murai $H$, Ueno $H$, Abe $H$, Komai $T$ : Mineralization and biodegradation of CSF shunting systems. J Neurosurg 67:584-591, 1987
4. Erdincler P, Kaynak MY, Canbaz B, Etus V, Dirican A, Ciplak $\mathrm{N}$, Kuday C: Spreading of ventriculo-peritoneal shunt complications over time: An analysis of 210 patients and 388 procedures covering a period of seven years. Turk Neurosurg $8: 1-5,1998$

5. Griebel RW, Hoffman HJ, Becker L: Calcium deposits on CSF shunts: Clinical observations and ultrastructural analysis. Childs Nerv Syst 3:180-182, 1987

6. Sakai $\mathrm{S}, \mathrm{Akai} \mathrm{T}$, lida $\mathrm{T}$, lizuka $\mathrm{H}$ : Calcification on the ventricle wall associated with a shunt tube--case report. Neurol Med Chir (Tokyo) 44:674-676, 2004

7. Shimotake K, Kondo A, Aoyama I, Nin K, Tashiro Y, Nishioka $\mathrm{T}$ : Calcification of a ventriculoperitoneal shunt tube. Case report. Surg Neurol 30:156-158, 1988

8. Stannard MW, Rollins NK: Subcutaneous catheter calcification in ventriculoperitoneal shunts. AJNR Am J Neuroradiol 16(6):1276-1278, 1995

9. Yamamoto S, Ohno K, Aoyagi M, Ichinose S, Hirakawa K: Calcific deposits on degraded shunt catheters: Long-term follow-up of V-P shunts and late complications in three cases. Childs Nerv Syst 18:19-25, 2002 